Article

\title{
Genetic Variability and Structure of Fragaria nilgerrensis Schlecht. Germplasm in Sichuan Province
}

\author{
Hongwen Li ${ }^{1,+}$, Snježana Bolarić ${ }^{2,+}$, Aleš Vokurka ${ }^{2, *}{ }^{\mathbb{D}}$, Jian He ${ }^{1}$, Dong Wang ${ }^{1}$, Xufeng Li ${ }^{3}$, Aleksandar Mešić ${ }^{2}$, \\ Jianhui Wang ${ }^{4}$ and Boris Duralija ${ }^{2}$ (i) \\ 1 Horticultural Research Institute, Sichuan Academy of Agricultural Sciences, Chengdu 610066, China; \\ cinalee@hotmail.com (H.L.); emailhejian@126.com (J.H.); wangdon2021@126.com (D.W.) \\ 2 Faculty of Agriculture, University of Zagreb, HR-10000 Zagreb, Croatia; sbolaric@agr.hr (S.B.); \\ amesic@agr.hr (A.M.); bduralija@agr.hr (B.D.) \\ 3 Key Laboratory of Bio-Resources and Eco-Environment, Ministry of Education, College of Life Science, \\ Sichuan University, Chengdu 610065, China; xfli@scu.edu.cn \\ 4 School of Food and Biological Engineering, Chengdu University, Chengdu 610106, China; \\ wangjianhui@cdu.edu.cn \\ * Correspondence: avokurka@agr.hr \\ + These authors contributed equally.
}

check for updates

Citation: Li, H.; Bolarić, S.; Vokurka, A.; He, J.; Wang, D.; Li, X.; Mešić, A.; Wang, J.; Duralija, B. Genetic

Variability and Structure of Fragaria nilgerrensis Schlecht. Germplasm in Sichuan Province. Horticulturae 2021, 7, 353. https://doi.org/10.3390/ horticulturae7100353

Academic Editor: Sergio

Ruffo Roberto

Received: 19 August 2021

Accepted: 26 September 2021

Published: 1 October 2021

Publisher's Note: MDPI stays neutral with regard to jurisdictional claims in published maps and institutional affiliations.

Copyright: (c) 2021 by the authors. Licensee MDPI, Basel, Switzerland. This article is an open access article distributed under the terms and conditions of the Creative Commons Attribution (CC BY) license (https:/ / creativecommons.org/licenses/by/ $4.0 /)$.

\begin{abstract}
Fragaria nilgerrensis Schlecht. (wild strawberry) is widely distributed in Southwest China, characterized by stress tolerance and the fruits of a notable peach aroma. So far there is only limited knowledge of variability and genetic structure in this species. Using AFLP markers, we investigated the genetic variability of 37 plants of F. nilgerrensis sampled in six main mountain areas of Sichuan Province and analyzed their genetic structure. Genetic similarity according to Nei and Li was used for cluster analysis based on UPGMA method and Agglomerative Hierarchical Clustering. Stratification of plants into more distinctive genetic groups was determined using Bayesian structure analysis. Six primer combinations produced a total of 1302 fragments of which 818 (62.8\%) were polymorphic. Bayesian analysis showed the 37 plants of $F$. nilgerrensis grouped into five distinctive genetic groups. Most of the plants from the same mountain area clustered into the same genetic group, indicating each area as an area with the unique genetic profile. The genetic parameters analyzed here indicate a huge genetic variability of $F$. nilgerrensis in Sichuan Province. Our results provide reference data for surveying and protecting the germplasm resources of $F$. nilgerrensis that could be used in strawberry breeding programs.
\end{abstract}

Keywords: F. nilgerrensis; wild strawberry; variability; AFLP; Bayesian cluster analysis

\section{Introduction}

China has more wild strawberry genetic resources than any other country in the world. Out of about 20 recognized Fragaria species [1], 14 species are distributed in China [2,3]. Therefore, China has been considered as a crucial geographical distribution center of wild strawberry resources [4]. Fragaria nilgerrensis Schlecht. is only one of the 14 wild Fragaria species present in China [2]. It is a perennial herbaceous plant of the Rosaceae family. It is a vigorous species, endemic to Southwest Asia, from the mountains of the Philippines, across Central and Southwestern China, to the hilly region of southern India. F. nilgerrensis is also distributed in the mountain regions of Southeast Asia. In China, F. nilgerrensis is distributed mainly in the mountain regions of Sichuan Province and the surrounding areas in Southwest China [5-7], but also in Yunnan Province [4].

F. nilgerrensis is a diploid wild strawberry $(2 \mathrm{n}=2 \mathrm{x}=14)$ [8] with a karyotype composed of six pairs of metacentric and one pair of submetacentric chromosomes [9]. The discovery of the narrow genetic base of the cultivated strawberry $[10,11]$ has sparked renewed interest in the use of wild Fragaria species in breeding programs. Lower ploidy Fragaria species 
$(2 x, 4 x$, and $6 x)$ with desirable characteristics, such as unique flavor, aroma, vigor, disease, pest resistance, and adaptability to a wide range of habitats, could potentially be used in breeding programs [12]. Species hybrids of $F$. nilgerrensis may produce plants with higher net carbon exchange rates (NCER) and/or increased dry matter accumulation at high temperatures [13].

Some specimens of $F$. nilgerrensis from Southwestern China have shown resistance to aphids and leaf diseases, have a strong peach aroma [14], and are resistant to waterlogging $[2,15]$. These desirable characteristics of $F$. nilgerrensis could be introduced into cultivated varieties by interspecific hybrids and back-crossing. For this reason, F. nilgerrensis may be excellent interspecific cross-material for improving the genetic divergence of cultivated strawberries [16]. To date, a few interspecific hybridizations were performed between F. nilgerrensis and F. $\times$ ananassa Duch. $[17,18]$, and also between F. nilgerrensis and F. nubicola F. pentaphylia, and F. viridis [19]. Until now, the genomic analysis of $F$. nilgerrensis was reported with a focus on the genetic basis of anthocyanin accumulation [4], sequencing of the full genome and phylogenetic analyses [11], sequencing of chloroplast genome in 10 wild strawberries species, including F. nilgerrensis [20], and comparative genomic analysis of Fragaria species, including F. nilgerrensis [21], but there has been no study on genetic divergence within the F. nilgerrensis. Phylogenic analysis of different wild strawberry species showed the outgroup of F. nilgerrensis from other diploid Fragaria species [22] but were always closer to diploid than other polyploid species [23].

Molecular markers are widely used for breeding purposes [24]. Amplified Fragment Length Polymorphism (AFLP) markers have been used successfully for fingerprinting and evaluating genetic variability in the germplasm of cultivated plants [14,25-32], including Fragaria species [16,33-40].

Knowing the genetic variability and genetic structure of F. nilgerrensis germplasm is the basis for conservation biology and possible genetic improvement of strawberry cultivars. Therefore, the hypothesis of this research is presumed existing huge genetic variability and detectable genetic stratification of the plants into more distinctive genetic groups, probably due to limitations of natural spreading among different mountain areas resulting in low to moderate flow of the genes among these populations.

The goals of the present study were to (1) estimate the genetic variability among genotypes of $F$. nilgerrensis and (2) determine the genetic stratification among genotypes to clarify genetic structure of $F$. nilgerrensis genotypes sampled from six main mountain areas in southwest China using AFLP markers. The data that is obtained may help us understand the genetic variability of $F$. nilgerrensis and provide a basis for its potential use in strawberry breeding programs.

\section{Materials and Methods}

\subsection{Plant Material}

Sichuan Provincial Department of Science and Technology is the relevant national regulatory body who permitted and encouraged our researchers to carry out the investigation, collection, evaluation, innovation, and utilization on Fragaria nilgerrensis Schlecht. resources in the national park or other protected areas of land.

Thirty-seven accessions of $F$. nilgerrensis were sampled in the six main mountain areas (MAs) in Sichuan Province in south west China. The collecting sites ranged from $26^{\circ} \mathrm{N}$ to $32^{\circ} \mathrm{N}$ latitude and from $101^{\circ} \mathrm{E}$ to $108^{\circ} \mathrm{E}$ longitude and were located at altitudes between 1034 and $3051 \mathrm{~m}$ (Table 1). The 37 sampled plants were propagated vegetatively, planted and maintained under the same cultivation conditions at the Horticultural Research Institute of the Sichuan Academy of Agricultural Sciences. Young fresh leaves from each plant were placed immediately into separate Ziploc plastic bags filled with dry silica gel for drying. The bags were then stored in a $-80{ }^{\circ} \mathrm{C}$ freezer. Details of the collection sites and sampled plants are listed in Table 1. 
Table 1. Sichuan Province locations (MAs) and plant codes of F. nilgerrensis used in this study. (Position: E, East; S, South; SW, South-West; NE, North-East; MS, Mid-South. Latitude, longitude, and altitude of the locations are indicated).

\begin{tabular}{|c|c|c|c|c|c|}
\hline $\begin{array}{l}\text { Mountain Area } \\
\text { (MA) Code }\end{array}$ & Plant Code & Position & Latitude & Longitude & Elevation (m a.s.l) \\
\hline \multirow{3}{*}{ MA 1} & PI 40 & $\mathrm{E}$ & $30^{\circ} 18^{\prime} \mathrm{N}$ & $106^{\circ} 47^{\prime} \mathrm{E}$ & 1450 \\
\hline & PI 41 & $\mathrm{E}$ & $30^{\circ} 17^{\prime} \mathrm{N}$ & $106^{\circ} 47^{\prime} \mathrm{E}$ & 1510 \\
\hline & PI 42 & $\mathrm{E}$ & $30^{\circ} 16^{\prime} \mathrm{N}$ & $106^{\circ} 47^{\prime} \mathrm{E}$ & 1560 \\
\hline \multirow{4}{*}{ MA 2} & PI 7 & $S$ & $28^{\circ} 12^{\prime} \mathrm{N}$ & $105^{\circ} 29^{\prime} \mathrm{E}$ & 1454 \\
\hline & PI 8 & $S$ & $28^{\circ} 11^{\prime} \mathrm{N}$ & $105^{\circ} 43^{\prime} \mathrm{E}$ & 1445 \\
\hline & PI 9 & S & $28^{\circ} 11^{\prime} \mathrm{N}$ & $105^{\circ} 44^{\prime} \mathrm{E}$ & 1368 \\
\hline & PI 10 & S & $28^{\circ} 16^{\prime} \mathrm{N}$ & $105^{\circ} 44^{\prime} \mathrm{E}$ & 1117 \\
\hline \multirow{3}{*}{ MA 3} & PI 1 & SW & $26^{\circ} 38^{\prime} \mathrm{N}$ & $101^{\circ} 40^{\prime} \mathrm{E}$ & 2509 \\
\hline & PI 3 & SW & $26^{\circ} 14^{\prime} \mathrm{N}$ & $101^{\circ} 43^{\prime} \mathrm{E}$ & 2104 \\
\hline & PI 92 & SW & $26^{\circ} 46^{\prime} \mathrm{N}$ & $101^{\circ} 31^{\prime} \mathrm{E}$ & 2364 \\
\hline \multirow{15}{*}{ MA 4} & PI 14 & MS & $29^{\circ} 49^{\prime} \mathrm{N}$ & $102^{\circ} 11^{\prime} \mathrm{E}$ & 1908 \\
\hline & PI 15 & MS & $29^{\circ} 42^{\prime} \mathrm{N}$ & $102^{\circ} 57^{\prime} \mathrm{E}$ & 1486 \\
\hline & PI 16 & MS & $29^{\circ} 41^{\prime} \mathrm{N}$ & $102^{\circ} 57^{\prime} \mathrm{E}$ & 1718 \\
\hline & PI 18 & MS & $29^{\circ} 38^{\prime} \mathrm{N}$ & $102^{\circ} 56^{\prime} \mathrm{E}$ & 2698 \\
\hline & PI 25 & MS & $29^{\circ} 32^{\prime} \mathrm{N}$ & $103^{\circ} 19^{\prime} \mathrm{E}$ & 2835 \\
\hline & PI 27 & MS & $29^{\circ} 31^{\prime} \mathrm{N}$ & $103^{\circ} 19^{\prime} \mathrm{E}$ & 2850 \\
\hline & PI 28 & MS & $29^{\circ} 31^{\prime} \mathrm{N}$ & $103^{\circ} 19^{\prime} \mathrm{E}$ & 2878 \\
\hline & PI 30 & MS & $29^{\circ} 31^{\prime} \mathrm{N}$ & $103^{\circ} 19^{\prime} \mathrm{E}$ & 2901 \\
\hline & PI 32 & MS & $29^{\circ} 32^{\prime} \mathrm{N}$ & $103^{\circ} 19^{\prime} \mathrm{E}$ & 2950 \\
\hline & PI 33 & MS & $29^{\circ} 32^{\prime} \mathrm{N}$ & $103^{\circ} 19^{\prime} \mathrm{E}$ & 2963 \\
\hline & PI 34 & MS & $29^{\circ} 32^{\prime} \mathrm{N}$ & $103^{\circ} 19^{\prime} \mathrm{E}$ & 2983 \\
\hline & PI 36 & MS & $29^{\circ} 32^{\prime} \mathrm{N}$ & $103^{\circ} 19^{\prime} \mathrm{E}$ & 2991 \\
\hline & PI 37 & MS & $29^{\circ} 32^{\prime} \mathrm{N}$ & $103^{\circ} 19^{\prime} \mathrm{E}$ & 3013 \\
\hline & PI 38 & MS & $29^{\circ} 32^{\prime} \mathrm{N}$ & $103^{\circ} 19^{\prime} \mathrm{E}$ & 3030 \\
\hline & PI 39 & MS & $29^{\circ} 32^{\prime} \mathrm{N}$ & $103^{\circ} 19^{\prime} \mathrm{E}$ & 3051 \\
\hline \multirow{7}{*}{ MA 5} & PI 50 & $\mathrm{NE}$ & $32^{\circ} 50^{\prime} \mathrm{N}$ & $104^{\circ} 17^{\prime} \mathrm{E}$ & 2906 \\
\hline & PI 95 & $\mathrm{NE}$ & $32^{\circ} 37^{\prime} \mathrm{N}$ & $107^{\circ} 01^{\prime} \mathrm{E}$ & 1034 \\
\hline & PI 96 & $\mathrm{NE}$ & $32^{\circ} 38^{\prime} \mathrm{N}$ & $107^{\circ} 03^{\prime} \mathrm{E}$ & 1273 \\
\hline & PI 97 & $\mathrm{NE}$ & $32^{\circ} 39^{\prime} \mathrm{N}$ & $107^{\circ} 04^{\prime} \mathrm{E}$ & 1614 \\
\hline & PI 98 & $\mathrm{NE}$ & $32^{\circ} 39^{\prime} \mathrm{N}$ & $106^{\circ} 03^{\prime} \mathrm{E}$ & 1761 \\
\hline & PI 99 & $\mathrm{NE}$ & $32^{\circ} 39^{\prime} \mathrm{N}$ & $107^{\circ} 02^{\prime} \mathrm{E}$ & 1865 \\
\hline & PI 104 & $\mathrm{NE}$ & $32^{\circ} 09^{\prime} \mathrm{N}$ & $108^{\circ} 13^{\prime} \mathrm{E}$ & 1105 \\
\hline \multirow{5}{*}{ MA 6} & PI 5 & SW & $27^{\circ} 34^{\prime} \mathrm{N}$ & $102^{\circ} 25^{\prime} \mathrm{E}$ & 2116 \\
\hline & PI 6 & SW & $27^{\circ} 34^{\prime} \mathrm{N}$ & $102^{\circ} 25^{\prime} \mathrm{E}$ & 2273 \\
\hline & PI 11 & SW & $28^{\circ} 28^{\prime} \mathrm{N}$ & $102^{\circ} 25^{\prime} \mathrm{E}$ & 2949 \\
\hline & PI 12 & SW & $28^{\circ} 41^{\prime} \mathrm{N}$ & $102^{\circ} 31^{\prime} \mathrm{E}$ & 1671 \\
\hline & PI 13 & SW & $29^{\circ} 14^{\prime} \mathrm{N}$ & $102^{\circ} 16^{\prime} \mathrm{E}$ & 1749 \\
\hline
\end{tabular}

\subsection{DNA Isolation}

Genomic DNA was isolated from $1 \mathrm{~g}$ of young fresh leaves using the modified cetyltrimethylammonium bromide (CTAB) method [41,42]. Dried leaves of 37 accessions were ground with liquid nitrogen in a mortar to a fine powder. The powder was transferred to a $10 \mathrm{~mL}$ tube, and $4 \mathrm{~mL}$ of $2 \%$ CTAB extraction buffer $\left(100 \mathrm{mmol} \mathrm{L}^{-1}\right.$ Tris- $\mathrm{HCl} \mathrm{pH} \mathrm{8.0,}$ $20 \mathrm{mmol} \mathrm{L}^{-1}$ EDTA (ethylenediaminetetraacetic acid), $1.4 \mathrm{~mol} \mathrm{~L}^{-1} \mathrm{NaCl}, 2 \% \mathrm{CTAB}, 1 \%$ PVP- $40,1 \%$ Vc. $10 \% \mathrm{Na}_{2} \mathrm{~S}_{2} \mathrm{O}_{5}$, and $2 \% \beta$-mercaptoethanol) was added into the tube, mixed well, and incubated at $65{ }^{\circ} \mathrm{C}$ for $30 \mathrm{~min}$ in a water bath. The suspension was mixed several times during incubation by inverting the tube. After cooling to room temperature, $1 \mathrm{~mL}$ of $5 \mathrm{M}$ potassium acetate was added and mixed well, and then the tube was placed in an ice bath for $20 \mathrm{~min}$. A total of $4 \mathrm{~mL}$ of chloroform-isoamyl alcohol (24:1 [v/v]) was added, and the sample was mixed by inverting the tube. The mixture was centrifuged at $12,000 \times g \mathrm{rpm}$ for $15 \mathrm{~min}$ at room temperature. The supernatant was transferred using cut pipette tips to a new $10 \mathrm{~mL}$ tube, then cold isopropanol $\left(-20^{\circ} \mathrm{C}\right)$ was added in a volume 
equivalent to $2 / 3$ the volume of the transferred supernatant. The tubes were inverted slowly several times to precipitate the DNA. The precipitated DNA was collected by glass capillary, transferred to a $1.5 \mathrm{~mL}$ tube, and washed twice in $500 \mu \mathrm{L}$ ice cold $75 \%(v / v)$ ethanol by inverting the tube. The final washing was performed in absolute ethanol, which was poured out, and the DNA was air-dried at room temperature. The DNA sample was dissolved in $0.5 \mathrm{~mL}$ T10E0.1 buffer in a $1.5 \mathrm{~mL}$ tube. RNase-A was added to a final concen-

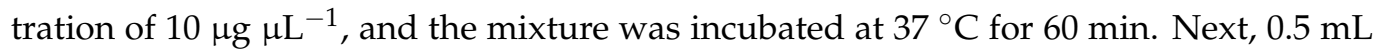
chloroform-isoamyl alcohol $(24: 1[v / v])$ was added, and the sample was mixed well and centrifuged at $12,000 \times \mathrm{g} \mathrm{rpm}$ for $15 \mathrm{~min}$ at $-4{ }^{\circ} \mathrm{C}$. The new supernatant was transferred into a new tube, and $1 / 10$ volume $(40 \mu \mathrm{L})$ of $3 \mathrm{M}$ of sodium acetate and 2 volumes $(0.8 \mathrm{~mL})$ of ice-cold absolute ethanol $\left(-20^{\circ} \mathrm{C}\right)$ were added and mixed well. The precipitated DNA was transferred into a new $1.5 \mathrm{~mL}$ tube, washed two times with absolute ethanol, air-dried at room temperature, and dissolved in $0.2 \mathrm{~mL}$ of double-distilled water. The quality of the isolated DNA was checked in $0.8 \%$ agarose gel in $0.5 x$ TBE buffer.

\subsection{Molecular Analysis}

To identify primer combinations that gave the optimal number of polymorphic bands, six plants of $F$. nilgerrensis were chosen randomly and analyzed using a total of 15 randomly selected primer combinations (primer screening) to detect the number of polymorphic bands. On the basis of numbers of scorable polymorphic bands, six highly polymorphic primer combinations were chosen and used to generate AFLP fragments for all 37 plants (Table 2).

Table 2. Oligonucleotide adapter and primer sequences used for the AFLP analysis.

\begin{tabular}{ll}
\hline Name & Sequence $\left(\mathbf{5}^{\prime} \rightarrow \mathbf{3}^{\prime}\right)$ \\
\hline EcoRI adaptor I & CTCGTAGACTGCGTACC \\
EcoRI adaptor II & AATTGGTACGCAGTC \\
\hline MseI adaptor I & GACGATGAGTCCTGAG \\
MseI adaptor II & TACTCAGGACTCAT \\
\hline Primers for preamplification & \\
EcoRI+A & GACTGCGTACCAATTC+A * \\
MseI+C & GATGAGTCCTGAGTAA+C * \\
\hline Primers for selective amplification & E+AAG/M+CAC \\
EcoRI-/MseI- primer combination) & E+AAG/M+CTA \\
& E+ACA/M+CAG \\
& E+ACC/M+CTT \\
& E+AGA/M+CAT \\
& E+AGT $/ \mathrm{M}+\mathrm{CAG}$ \\
\hline
\end{tabular}

* indicates the additional selective nucleotide for the adaptors.

The AFLP analysis was carried out in the biotechnology laboratory at the Faculty of Agriculture, University of Zagreb, Croatia, according to the method described by Vos et al. [43], with modifications described below. Briefly, $0.2 \mu \mathrm{g}$ samples of the genomic DNA of F. nilgerrensis were double digested using EcoRI and MseI restriction enzymes (New England BioLabs ${ }^{\circledR}$, Ipswich, MA, USA). The EcoRI and MseI adapters and primers for preselective and selective amplifications were synthesized by Applied Biosystems (Foster City, CA, USA). Ligase (Fermentas, Vilnius, Lithuania) was used to ligate the EcoRI and MseI adapters to the ends of the DNA fragments. The adapter-ligated DNA was diluted with $75 \mu \mathrm{L}$ of $\mathrm{T}_{10} \mathrm{E}_{0.1}$ buffer and subjected to preselective amplification using the synthesized EcoRI and MseI primers that consisted of a core sequence and an enzyme-specific sequence [43], except that each primer had one additionally selective nucleotide (EcoRI+A, $\mathrm{Mse} \mathrm{I}+\mathrm{C})$. The preselective amplification reaction was performed in a total volume of $20 \mu \mathrm{L}$ containing 1x PCR buffer, $3 \mathrm{mM} \mathrm{MgCl} 2,0.2 \mathrm{mM}$ dNTP (Fermentas), $0.25 \mu \mathrm{M}$ of each primer, $0.5 \mathrm{U}$ Taq polymerase (Sigma, St. Louis, MO, USA), and $5 \mu \mathrm{L}$ double-digested and adapter-ligated DNA. PCR amplification was performed in a Veriti ${ }^{\circledR} 96$-well thermal cycler 
(Applied Biosystem) using one step of $2 \mathrm{~min}$ at $72{ }^{\circ} \mathrm{C}, 20$ cycles of $20 \mathrm{~s}$ at $94{ }^{\circ} \mathrm{C}, 30 \mathrm{~s}$ at $56{ }^{\circ} \mathrm{C}$, and $2 \mathrm{~min}$ at $72{ }^{\circ} \mathrm{C}$, with a final elongation step of $30 \mathrm{~min}$ at $60^{\circ} \mathrm{C}$. The preselective amplification products were diluted 25 times in $\mathrm{T}_{10} \mathrm{E}_{0.1}$ buffer. Selective amplification was carried out using EcoRI and MseI primers with three additional selective nucleotides (Table 2). Each of the forward primers (EcoRI primers) were labeled with one of the following fluorescent dyes: 6-FAM, VIC, NED, or PET. The selective amplification reaction was performed in a total volume of $20 \mu \mathrm{L}$ containing $1 \mathrm{x}$ PCR buffer, $3 \mathrm{mM} \mathrm{MgCl}, 0.2 \mathrm{mM}$ dNTP (Fermentas), $0.25 \mu \mathrm{M}$ of each primer (Applied Biosystems), $0.5 \mathrm{U}$ Taq polymerase (Sigma), and $5 \mu \mathrm{L}$ preselective amplification product (1:25). Selective amplification was performed using a touchdown protocol with one step of $2 \mathrm{~min}$ at $94{ }^{\circ} \mathrm{C}, 10$ cycles of $20 \mathrm{~s}$ at $94{ }^{\circ} \mathrm{C}, 30 \mathrm{~s}$ at $66^{\circ} \mathrm{C}\left(-1^{\circ} \mathrm{C}\right.$ per cycle $)$, and $2 \mathrm{~min}$ at $72{ }^{\circ} \mathrm{C}$, followed by 20 cycles of $20 \mathrm{~s}$ at $94{ }^{\circ} \mathrm{C}, 30 \mathrm{~s}$ at $56^{\circ} \mathrm{C}$, and $2 \mathrm{~min}$ at $72{ }^{\circ} \mathrm{C}$, with a final elongation step of $30 \mathrm{~min}$ at $60^{\circ} \mathrm{C}$. After selective amplification, the PCR products were diluted in double deionized water in the

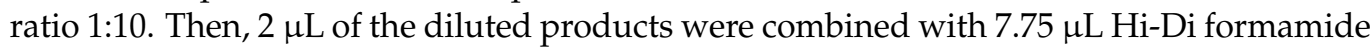
(Applied Biosystems) and 0.25 $\mu \mathrm{L}$ of Gene-Scan-600 LIZ internal size standard (Applied Biosystems) and denatured at $95^{\circ} \mathrm{C}$ for $5 \mathrm{~min}$. Separation of the AFLP fragments was carried out in a four-capillary ABI 3130 Genetic Analyzer (Applied Biosystems) using the POP-7 polymer and 36-cm capillaries and analyzed using the GeneMapper V 4.0 software (Applied Biosystems).

The AFLP fragments within the range of 50 to 500 bp were scored by GeneMapper v.4.0 software (Applied Biosystems). The GeneMapper output data based on the size and the height of AFLP fragments also included four replicates of DNA samples added as duplicates and three samples as negative controls. Additional AFLP fragment selection was achieved by the ScanAFLP 1.3 software [44], excluding those fragments with peaks lower than $50 \mathrm{rfu}$, those with heights lower than $10 \%$ of the mean height of the maximum height frequency class and those with coefficient of variation higher than one, and fragments which differed in more than one fragment among replicates. The binary matrix obtained after such a systematic elimination of dubious fragments was used for subsequent statistical analysis.

\subsection{Data Analysis}

The AFLP binary matrix was used for calculation of polymorphic information content (PIC) per primer combination for calculating the genetic similarity between individuals $\left(S_{N L}\right)$, for UPGMA, and for the Bayesian STRUCTURE analysis [45].

The polymorphism information content (PIC) for each AFLP fragment was calculated using the following formula [46]:

$$
P I C_{i}=2 f_{i}\left(1-f_{i}\right)
$$

where $P I C_{i}$ is the polymorphic information content of marker $i, f_{i}$ is the frequency of the AFLP fragments that are present, and $1-f_{i}$ is the frequency of AFLP fragments that are absent. The PIC value for dominant markers is up to 0.50 for $f_{i}=0.50$ [47].

Genetic similarity between individuals $\left(S_{N L}\right)$ was calculated according to Nei-Li $[48,49]$. The similarity matrix was constructed on the coefficient of similarities between all pairs of 37 accessions of F. nilgerrensis. Cluster analysis based on the UPGMA method using Agglomerative Hierarchical Clustering (AHC) was carried out using XLSTAT Version 2021.1.1 software [50]. Bootstrap analysis based on 1000 resamplings of the data set was computed using software NTSYSpc ver. 2.21L [51].

The level of genetic stratification $(K)$ (the modal value of $\Delta K$ ) among the F. nilgerrensis plants was assessed using Bayesian clustering analysis incorporated in the STRUCTURE ver. 2.3.4 software [45]. Bayesian cluster analyses included a burn-in period (initial stage of the sampling process) of 10,000 replicates, followed by 10,000 Markov chain Monte Carlo (MCMC) replicates for each run. Twenty repeat runs were carried out to quantify the amount of variation of the likelihood for each $K$ (from $K=1$ to $K=6$ ), using an ADMIXTURE model and correlated allele frequencies and allowing for recessive alleles [52]. The posterior probability of the data $\ln P(K)$ for a given $K$ can be used as an indication of the most likely 
number of distinctive groups or subpopulations [53]. Therefore, the height of the modal value of the $\Delta K$ distribution was calculated to detect the number of distinctive groups $K$ using Structure Harvester v 0.6.92 [54]. The $K$ that best described the data was chosen by examining the $\ln P(K)$ [55] and by calculating $\Delta K$, as described by Evanno et al. [53]. The value of $K$ with the highest mean $\log$ likelihood $[\ln P(K)]$ and $\Delta K$ statistic was selected.

\section{Results}

After applying ScanAFLP 1.3 software [44], the initial dataset of polymorphic AFLP fragments based on six primer combinations dropped from 1302 to 818, with the estimated error rate between $0.73 \%$ and $1.69 \%$ per primer combination, with a mean of $1.07 \%$, which is within the usual range for AFLP data [56]. The number of polymorphic fragments by an individual primer combination varied from 105 (E+AAG/M+CTA) to $182(\mathrm{E}+\mathrm{AGA} / \mathrm{M}+\mathrm{CAT})$, with an average of 136.3 (Table 3$)$. The average PIC value ranged from $0.26(\mathrm{E}+\mathrm{AGA} / \mathrm{M}+\mathrm{CAT})$ to $0.31(\mathrm{E}+\mathrm{ACA} / \mathrm{M}+\mathrm{CAG})$ with an average of 0.29 per primer combination (Table 3).

Table 3. AFLP primer combinations, total number of scorable fragments, number and percentage of polymorphic fragments, and polymorphic information content (PIC) per primer combination in 37 F. nilgerrensis plants using AFLP markers.

\begin{tabular}{llll}
\hline AFLP Primer Combination & Total Number of Fragments & $\begin{array}{l}\text { Number and Percentage (\%) of } \\
\text { Polymorphic Fragments }\end{array}$ & PIC \\
\hline E $^{\mathrm{a}}+\mathrm{AAG} / \mathrm{M}^{\mathrm{b}}+\mathrm{CAC}$ & 206 & $124(60.2 \%)$ & 0.30 \\
E+AGT/M+CAG & 244 & $165(67.6 \%)$ & 0.28 \\
E+AGA/M+CAT & 245 & $182(74.3 \%)$ & 0.26 \\
E+ACC/M+CTT & 210 & $130(61.9 \%)$ & 0.27 \\
E+AAG/M+CTA & 190 & $105(55.3 \%)$ & 0.29 \\
E+ACA/M+CAG & 207 & $112(54.1 \%)$ & 0.31 \\
\hline Total & 1302 & 818 & - \\
Average & 217 & $136.3(62.8 \%)$ & 0.29 \\
\hline
\end{tabular}

a Primer core sequence specific for EcoRI site: 5'-GACTGCGTACCAATTC-3'. ' b Primer core sequence specific for MseI site: 5'GATGAGTCCTGAGTAA-3'

Similarity coefficients $\left(S_{N L}\right)$ between the 37 F. nilgerrensis plants ranged from 0.17 (PI 1 vs. PI 96) to 0.95 (PI 95 and PI 96). UPGMA clustering divided the plants into six groups (Figure 1a). Most of the plants from the same mountain area clustered into the same group, but there were some exceptions: part of the plants from the mountain area MA 4 clustered together with the plants originated from mountain area MA 5, while plants originated from MA 6 clustered under two separated clusters (Figure 1a).

Bayesian clustering analysis was used to test the population structures; one to six clusters $(K)$ were tested. Average $\log$ probability $\ln P(K)$ values increased to the fifth testing cluster, after which the rate of change in the log probability value decreased dramatically (Figure 2).

The relationship between $K$ and $\Delta K$ indicated that the 37 plants of $F$. nilgerrensis clustered into five distinctive genetic groups (Figure 1b). The plants from mountain areas MA 1 and MA 5 and four plants from mountain areas MA 4 (PI 14, PI 15, PI 16, and PI 18) belong to genetic group $K 1$. The four plants from MA 4 group probably belonged to the bordering area between the genetic groups $K 1$ and $K 2$ and possessed different proportions of the genes from the neighboring genetic groups. The remaining 11 plants from mountain area MA 4 cluster in a separate genetic group $K 2$. The plants from mountain areas MA 6 , MA 2, and MA 3 cluster separately in the remaining three genetic groups $K 3, K 4$, and $K 5$, respectively. 


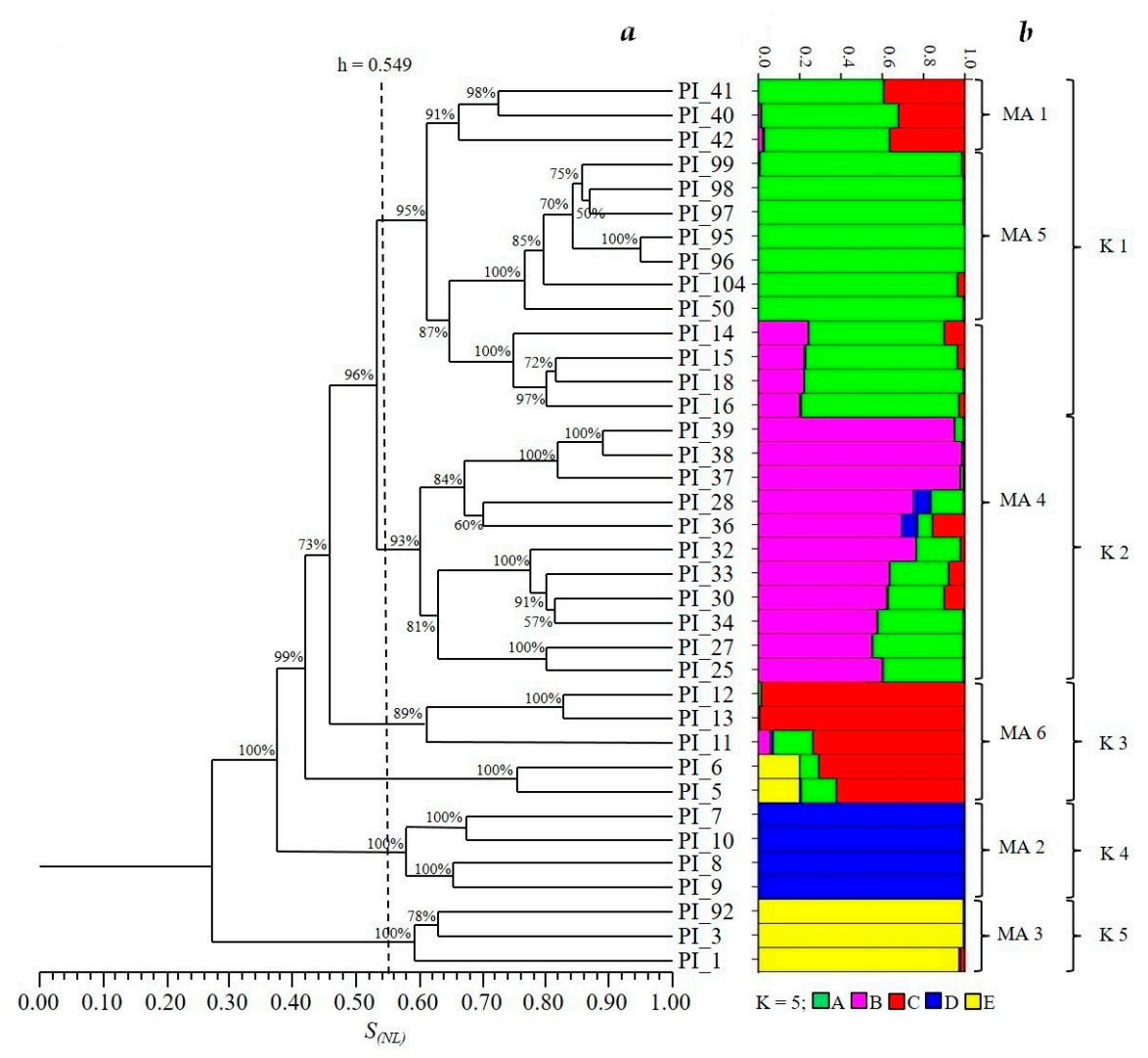

Figure 1. The dendrogram (a) based on the similarity coefficient $\left(S_{N L}\right)$ and UPGMA using Agglomerative Hierarchical Clustering of 37 accessions of F. nilgerrensis based on AFLP markers. A threshold (h) was used to separate six clusters. Bootstrap values over $50 \%$ based on 1000 resamplings of the data set are indicated on the branches of dendrogram. The mountain areas (MAs) and plant codes are listed in Table 1. (b) Bayesian cluster analysis of the 37 samples of F. nilgerrensis. Subpopulations $(K)$ are indicated at the right side of the bar plot. The strips of different colors represent membership coefficients for $K=5$, calculated by STRUCTURE software.

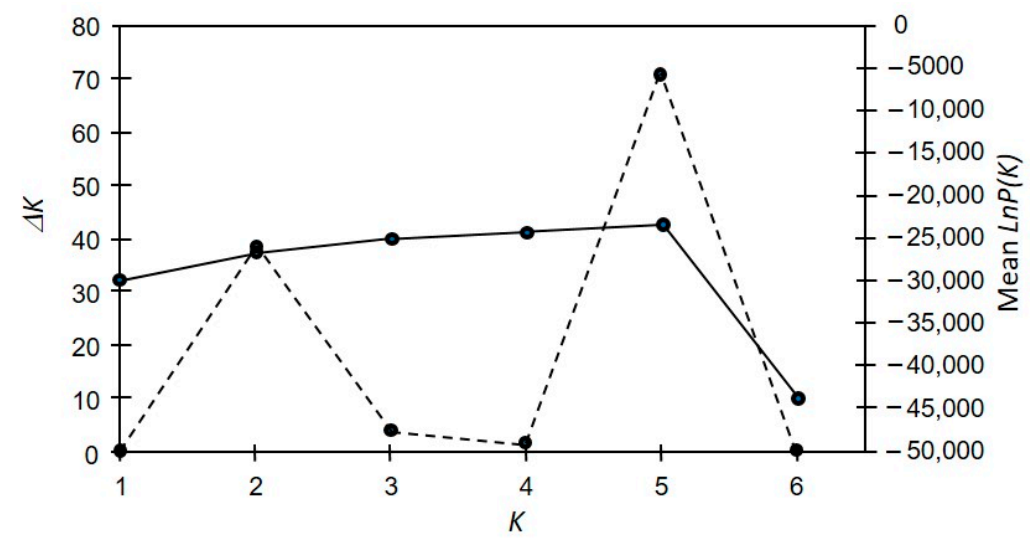

Figure 2. Bayesian clustering of $37 \mathrm{~F}$. nilgerrensis plants. The average log probability value $\operatorname{Ln} P(K)$ (solid line) and modal value of $\Delta \mathrm{K}$ (dashed line) or distinctive genetic groups $K$ are shown. The $\Delta K$ values are based on 20 replicates for each value of $K$ using the ADMIXTURE method.

An exchange of genes in the neighboring area between genetic groups $K 1$ and $K 3$ and between $K 3$ and $K 5$ also seems to have occurred, but to a lesser extent.

The mean value of membership coefficients of F. nilgerrensis, sampled in six mountain areas in Sichuan province was calculated by each mountain area on the basis of membership 
coefficients for $K=5$ for 37 plants (pie charts in Figure 3). The majority of genetic basis shown in percentages in the pie charts, as revealed by STRUCTURE, is exchanged among MA 1 and MA 5 in one side (green) and MA 4 and MA 6 in the other side, and also among MA 6 (red) and MA 1. The genetic basis of the plants from MA 2 (blue) is $100 \%$ unique (without exchange), while MA 3 (yellow) and MA 5 (green) are almost unique, with just a gentle exchange with other groups of $1 \%$ on average. The main reason for that is probably the limited possibility of the spreading of generative and vegetative propagation material among distant mountain areas.

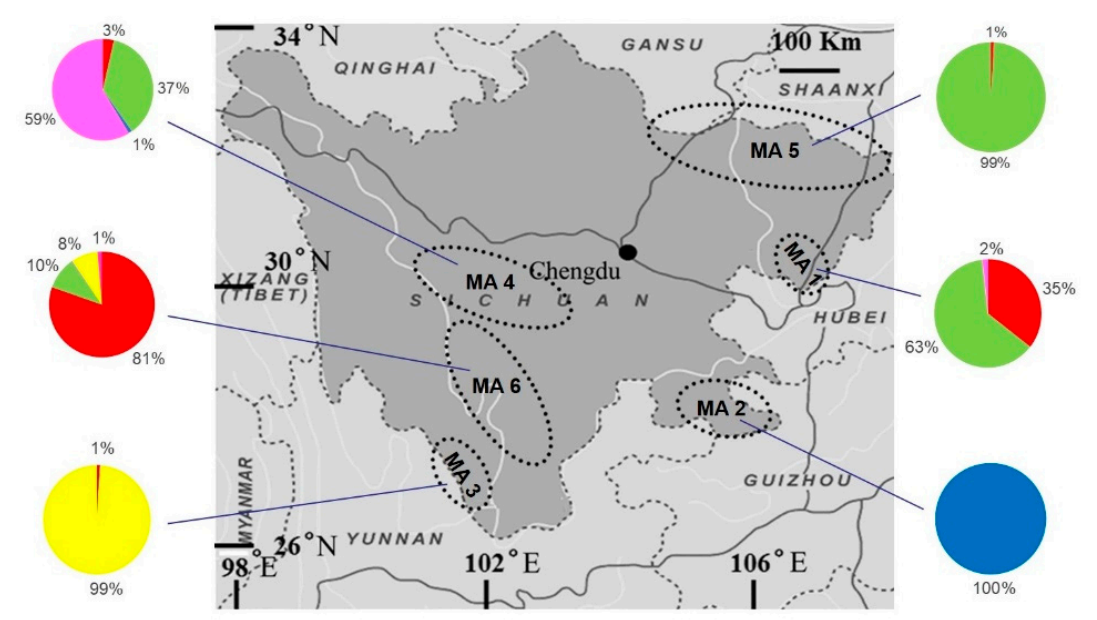

Figure 3. Map of Sichuan Province with the six main mountain areas (MAs) marked. MA 1 to MA 6 are the six origin areas of 37 plants of F. nilgerrensis. Pie charts represent membership coefficients for $K=5$ calculated by STRUCTURE averaged by mountain areas for plants of $F$. nilgerrensis collected in Sichuan province.

\section{Discussion}

Here we have used AFLP molecular markers to investigate the genetic variability in F. nilgerrensis. The study has revealed the wide range of genetic variability in the germplasm of $F$. nilgerrensis collected in the six main mountain areas of Sichuan province in Southwestern China.

The AFLP technique has been widely recognized as the most efficient marker system when compared to RFLP, RAPD, and SSR [25]. In a study on their application in F. $\mathrm{x}$ ananassa [35], AFLP markers generated from any one of the four pairs of primer combinations were sufficient to distinguish among 19 cultivars, some of which were closely related, identifying in total 228 scorable markers and demonstrating high effectiveness in the fingerprinting of strawberry cultivars. In a similar study, Tyrka et al. [36] obtained 129 scorable markers using 10 AFLP primer combinations.

In the present study, we obtained 818 scorable markers using six AFLP primer combinations. The number of scorable markers is affected by the method used for marker visualization. Degani et al. [35] used radioactively labeled primers, and Tyrka et al. [36] used agarose gel for marker separation. In our study, the large number of scorable markers was obtained using a highly susceptible fluorescence-based detection system with four-capillary electrophoresis. Our result is consistent with the findings [57] that a significantly larger number of markers was obtained with a fluorescence-based detection system compared to radiolabeling.

Zhang et al. [37] reported that the percentage of AFLP polymorphisms in 107 strawberry (F. ananassa Duch.) cultivars was 70.9\%. Degani et al. [35] found that $84.6 \%$ of the AFLP fragments in 19 strawberry cultivars were polymorphic, using four primer combinations. Tyrka et al. [36] detected $89.92 \%$ of the AFLP fragments to be polymorphic in 19 strawberry clones, using 10 primer combinations. In our study, the six primer combinations revealed a lower genetic variability $(62.8 \%)$ in F. nilgerrensis compared to the 
polymorphisms detected in the cultivars and clones of $F$. ananassa reported in the previous studies. Regarding the other strawberry species, and other marker systems, Fragaria chiloensis ssp. chiloensis $\mathrm{f}$. chiloensis revealed $48 \%$ of polymorphic ISSR fragments, while F. chiloensis ssp. chiloensis f. patagonica showed higher variability of $90 \%$ of polymorphic markers [58]. F. nubicola also exhibits higher variability of SSR markers, reaching as high as $88.9 \%$ [59].

The cluster analysis based on the similarity coefficients showed that all 37 plants of $F$. nilgerrensis collected in six mountain areas in Sichuan province separated into five differentiated genetic groups. The dendrogram (Figure 1a) indicated that the geographically determined groups of plants located in the southwest, south, east, northeast and mid-south of Sichuan province were relatively independent genetic groups.

Three of the six mountain areas (MA 2, MA 3, and MA 5) represent unique genetic groups of the F. nilgerrensis germplasm in Sichuan (pie charts in Figure 1), meaning each of these three mountain areas groups consist of mainly unique and independent genetic profiles with admixtures up to $1 \%$. Another two mountain areas (MA 4 and MA 6) are characterized by higher contribution of admixtures from more genetic groups, but these areas may still be considered to be areas with unique genetic profiles. Only one area (MA 1) may be considered as an admixture of two genetic profiles.

Following these results, we may conclude that individuals within each mountain area adapted to specific environmental conditions during the long-term natural selection. In a recent study, Lu et al. [60] analyzed the genetic structure of 16 populations and 169 individuals of $F$. nilgerrensis using 16 EST-ISSR markers and found all the populations separated in two genetic groups, with some individuals admixed. The principal aim of this study was to clarify if the genetic structure of wild strawberry F. nilgerrensis existed in the mountain areas of Sichuan Province. Bayesian STRUCTURE analysis revealed that five distinct genetic groups existed in Sichuan Province, indicating higher genetic variability in comparison to the above mentioned study.

\section{Conclusions}

Our findings clearly show that all 37 plants of F. nilgerrensis collected in Sichuan Province belong to five genetic groups. The identification of five distinct genetic groups may help to narrow the classification and evaluation of the whole $F$. nilgerrensis genetic pool within the germplasm collections and provide a clearer insight into the genetic structure of the sampled material, which will help breeders in setting up hybridization schemes.

Author Contributions: Conceptualization, H.L. and A.V.; methodology, H.L. and S.B.; software, J.H. and S.B.; validation, H.L. and D.W.; formal analysis, S.B. and J.H.; investigation, J.H., D.W. and H.L.; resources, H.L., X.L. and B.D.; data curation, A.M. and D.W.; writing-original draft preparation, J.H.; writing-review and editing, J.H., A.V. and S.B.; visualization, J.W. and A.M.; supervision, H.L., D.W. and X.L.; project administration, H.L., J.W. and B.D.; funding acquisition, H.L., X.L. and B.D. All authors have read and agreed to the published version of the manuscript.

Funding: This research was funded by The Ministry of Science, Education, and Sports of the Republic of Croatia, Research project number 178-1191193-1943. The APC was funded by Horticultural Research Institute, Sichuan Academy of Agricultural Sciences, Chengdu, China. Results shown in this paper arise from the research project (Biodiversity of edible wild fruit populations in CroatiaProject number 178-1191193-1943), carried out by the support of The Ministry of Science, Education, and Sports of the Republic of Croatia.

Conflicts of Interest: The authors declare no conflict of interest. The funders had no role in the design of the study; in the collection, analyses, or interpretation of data; in the writing of the manuscript, or in the decision to publish the results.

\section{References}

1. Stauct, G. The Species of Fragaria, Their Taxonomy and Geographical Distribution. Available online: http://www.actahort.org/ books/265/265_1.htm (accessed on 15 August 2021). 
2. Guo, R.; Xue, L.; Luo, G.; Zhang, T.; Lei, J. Investigation and taxonomy of wild Fragaria resources in Tibet, China. Genet. Resour. Crop. Evol. 2017, 65, 405-415. [CrossRef]

3. Lei, J.; Xue, L.; Guo, R.; Dai, H. The Fragaria species native to China and their geographical distribution. Acta Hortic. 2017, 37-46. [CrossRef]

4. Zhang, J.; Lei, Y.; Wang, B.; Li, S.; Yu, S.; Wang, Y.; Li, H.; Liu, Y.; Ma, Y.; Dai, H.; et al. The high-quality genome of diploid strawberry (Fragaria nilgerrensis) provides new insights into anthocyanin accumulation. Plant Biotechnol. J. 2020, 18, $1908-1924$. [CrossRef] [PubMed]

5. Chao, W.J.; Zhong, X. Studies on resources of wild strawberry in Qing-Ba mountain area. Crop. Var. Resour. 1988, 3, 15-18.

6. Lei, J.J.; Yang, G.; Dai, H.P.; Wu, L.P.; Deng, M.Q. Strawberry wild resources in China. J. Fruit Sci. 1997, 14, 198-200.

7. Lei, J.J.; Dai, H.P.; Tan, C.H.; Deng, M.Q.; Zhao, M.Z.; Qian, Y.M. Studies on the taxonomy of the strawberry (Fragaria) species distributed in China. Acta Hortic. Sin. 2006, 33, 1-5.

8. Qiao, Q.; Xue, L.; Wang, Q.; Sun, H.; Zhong, Y.; Huang, J.; Lei, J.; Zhang, T. Comparative Transcriptomics of Strawberries (Fragaria spp.) Provides Insights into Evolutionary Patterns. Front. Plant Sci. 2016, 7, 1839. [CrossRef]

9. Rho, I.R.; Hwang, Y.J.; Lee, H.I.; Lee, C.-H.; Lim, K.B. Karyotype analysis using FISH (fluorescence in situ hybridization) in Fragaria. Sci. Hortic. 2012, 136, 95-100. [CrossRef]

10. Sjulin, T.M.; Dale, A. Genetic Diversity of North American Strawberry Cultivars. J. Am. Soc. Hortic. Sci. 1987, 112, $375-385$.

11. Feng, C.; Wang, J.; Harris, A.J.; Folta, K.M.; Zhao, M.; Kang, M. Tracing the Diploid Ancestry of the Cultivated Octoploid Strawberry. Mol. Biol. Evol. 2021, 38, 478-485. [CrossRef]

12. Harbut, R.M.; Sullivan, J.A. Breeding Potential of Lower Ploidy Fragaria Species. J. Am. Pom. Soc. 2004, 58, 37-41.

13. Harbut, R.; Sullivan, J.; Proctor, J. Temperature affects dry matter production and net carbon exchange rate of lower-ploidy Fragaria species and species hybrids. Can. J. Plant Sci. 2010, 90, 885-892. [CrossRef]

14. Li, H.-W.; Liu, J.-J.; Chen, K.-L.; He, J.; Guan, B.; Wang, J.-H. Investigation and Collection and Evaluation on Wild Strawberry Resources in Sichuan and Neighboring Regions. J. Plant Genet. Resour. 2012, 13, 946-951.

15. Luo, G.; Xue, L.; Guo, R.; Ding, Y.; Xu, W.; Lei, J. Creating interspecific hybrids with improved cold resistance in Fragaria. Sci. Hortic. 2018, 234, 1-9. [CrossRef]

16. Park, Y.-J.; Yoon, M.-Y.; Moe, K.T.; Kim, D.-Y.; Rho, I.-R.; Kim, S.; Kim, K.-T.; Won, M.-K.; Chung, J.-W. Genetic diversity and population structure analysis of strawberry (Fragaria $\mathrm{x}$ ananassa Duch.) using SSR markers. Electron. J. Biotechnol. 2012, 15. [CrossRef]

17. Noguchi, Y.; Mochizuki, T.; Sone, K. Breeding of a New Aromatic Strawberry by Interspecific Hybridization Fragaria $\mathrm{x}$ ananassa $\times$ F. nilgerrensis. J. Jpn. Soc. Hortic. Sci. 2002, 71, 208-213. [CrossRef]

18. Ma, H.X.; Chen, P.D. Production and cytogentics of interspecific hybrids from the cross of Fragaria nilgerrensis Schlecht. and F. ananassa Duch. Sci. Agric. Sin. 2004, 37, 1966-1970.

19. Bors, R.; Sullivan, J. Interspecific Hybridization of Fragaria vesca subspecies with F. nilgerrensis, F. nubicola, F. pentaphylla, and F. viridis. J. Am. Soc. Hortic. Sci. 2005, 130, 418-423. [CrossRef]

20. Sun, J.; Sun, R.; Liu, H.; Chang, L.; Li, S.; Zhao, M.; Shennan, C.; Lei, J.; Dong, J.; Zhong, C.; et al. Complete chloroplast genome sequencing of ten wild Fragaria species in China provides evidence for phylogenetic evolution of Fragaria. Genomics 2021, 113, 1170-1179. [CrossRef]

21. Edger, P.P.; McKain, M.R.; Yocca, A.E.; Knapp, S.J.; Qiao, Q.; Zhang, T. Reply to: Revisiting the origin of octoploid strawberry. Nat. Genet. 2020, 52, 5-7. [CrossRef]

22. Chambers, A.; Carle, S.; Njuguna, W.; Chamala, S.; Bassil, N.; Whitaker, V.M.; Barbazuk, W.B.; Folta, K.M. A genome-enabled, high-throughput, and multiplexed fingerprinting platform for strawberry (Fragaria L.). Mol. Breed. 2013, 31, 615-629. [CrossRef]

23. Yang, Y.; Davis, T.M. A New Perspective on Polyploid Fragaria (Strawberry) Genome Composition Based on Large-Scale, Multi-Locus Phylogenetic Analysis. Genome Biol. Evol. 2017, 9, 3433-3448. [CrossRef] [PubMed]

24. Iqbal, M.; Shahzad, R.; Shahzad, R.; Bilal, K.; Qaisar, R.; Nisar, A.; Kanwal, S.; Bhatti, M. DNA Fingerprinting of Crops and Its Applications in the Field of Plant Breeding. J. Agric. Res. 2021, 59, 13-28.

25. Steiger, D.; Nagai, C.; Moore, P.; Morden, C.; Osgood, R.; Ming, R. AFLP analysis of genetic diversity within and among Coffea arabica cultivars. Theor. Appl. Genet. 2002, 105, 209-215. [CrossRef] [PubMed]

26. Xu, D.H.; Wahyuni, S.; Sato, Y.; Yamaguchi, M.; Tsunematsu, H.; Ban, T. Genetic Diversity and Relationships of Japanese Peach (Prunus persica L.) Cultivars Revealed by AFLP and Pedigree Tracing. Genet. Resour. Crop. Evol. 2006, 53, 883-889. [CrossRef]

27. Warwick, S.I.; Gugel, R.K.; McDonald, T.M.; Falk, K.C. Genetic Variation of Ethiopian Mustard (Brassica carinata A. Braun) Germplasm in Western Canada. Genet. Resour. Crop. Evol. 2006, 53, 297-312. [CrossRef]

28. Yang, J.; Qian, Z.-Q.; Liu, Z.-L.; Li, S.; Sun, G.-L.; Zhao, G.-F. Genetic diversity and geographical differentiation of Dipteronia Oliv. (Aceraceae) endemic to China as revealed by AFLP analysis. Biochem. Syst. Ecol. 2007, 35, 593-599. [CrossRef]

29. Yuan, Z.; Yin, Y.; Qu, J.; Zhu, L.; Li, Y. Population Genetic Diversity in Chinese Pomegranate (Punica granatum L.) Cultivars Revealed by Fluorescent-AFLP Markers. J. Genet. Genom. 2007, 34, 1061-1071. [CrossRef]

30. Elameen, A.; Fjellheim, S.; Larsen, A.; Rognli, O.A.; Sundheim, L.; Msolla, S.; Masumba, E.; Mtunda, K.; Klemsdal, S.S. Analysis of genetic diversity in a sweet potato (Ipomoea batatas L.) germplasm collection from Tanzania as revealed by AFLP. Genet. Resour. Crop. Evol. 2008, 55, 397-408. [CrossRef] 
31. Li, M. Genetic Diversity and Relationship of Flax Germplasm as Revealed by AFLP Analysis. Acta Agron. Sin. 2011, 37, 635-640. [CrossRef]

32. Lv, T.; Harris, A.; Liu, Y.; Liu, T.; Liang, R.; Ma, Z.; Su, X. Population genetic structure and evolutionary history of Psammochloa villosa (Trin.) Bor (Poaceae) revealed by AFLP marker. Ecol. Evol. 2021, 11, 10258-10276. [CrossRef] [PubMed]

33. Graham, J.; McNicol, R.J.; McNicol, J.W. A comparison of methods for the estimation of genetic diversity in strawberry cultivars. Theor. Appl. Genet. 1996, 93, 402-406. [CrossRef] [PubMed]

34. Benoit, V.; Etienne, C.; Denoyes-Rothan, B. Genetic Diversity of Strawberry Genotypes from Fragaria x Ananassa and F. vesca Revealed by Amplified Fragment Length Polymorphism (AFLP) Analysis. In Proceedings of the 8th Conference, San Diego, CA, USA, 9 January 2000.

35. Degani, C.; Rowland, L.J.; Saunders, J.A.; Hokanson, S.C.; Ogden, E.L.; Golan-Goldhirsh, A.; Galletta, G.J. A comparison of genetic relationship measures in strawberry (Fragaria $\times$ ananassa Duch.) based on AFLPs, RAPDs, and pedigree data. Euphytica 2001, 117, 1-12. [CrossRef]

36. Tyrka, M.; Dziadczyk, P.; Hortyński, J.A. Simplified AFLP procedure as a tool for identification of strawberry cultivars and advanced breeding lines. Euphytica 2002, 125, 273-280. [CrossRef]

37. Zhang, Y.T.; Feng, Z.G.; Li, T.Z.; Dong, J.; Wang, G.X.; Zhang, K.C. Genetic Relationships of Strawberry Cultivars by AFLP Analysis. Acta Hortic. Sin. 2006, 33, 1199-1202.

38. KangHee, C.; IlRae, R.; YongSeop, C.; PueHee, P. Analysis of genetic diversity of strawberry (Fragaria $\times$ ananassa Duch.) cultivars using AFLP and SSR markers. Korean J. Breed. Sci. 2007, 39, 447-456.

39. Njuguna, W. Development and Use of Molecular Tools in Fragaria; Oregon State University: Corvallis, OR, USA, 2010.

40. Kunihisa, M. Studies Using DNA Markers in Fragaria $\times$ ananassa: Genetic Analysis, Genome Structure, and Cultivar Identification. J. Jpn. Soc. Hortic. Sci. 2011, 80, 231-243. [CrossRef]

41. Wang, G.L.; Fang, H.J. Plant Gene Engineering Principles and Techniques; Beijing Science Press: Beijing, China, 1998; pp. 370-375.

42. Doyle, J.J.; Doyle, J.L. Isolation of Plant DNA from Fesh Tissue. Focus 1990, 12, 13-15.

43. Vos, P.; Hogers, R.; Bleeker, M.; Reijans, M.; Van De Lee, T.; Hornes, M.; Friters, A.; Pot, J.; Paleman, J.; Kuiper, M.; et al. AFLP: A new technique for DNA fingerprinting. Nucleic Acids Res. 1995, 23, 4407-4414. [CrossRef]

44. Herrmann, D.; Poncet, B.N.; Manel, S.; Rioux, D.; Gielly, L.; Taberlet, P.; Gugerli, F. Selection criteria for scoring amplified fragment length polymorphisms (AFLPs) positively affect the reliability of population genetic parameter estimates. Genome 2010, 53, 302-310. [CrossRef]

45. Falush, D.; Stephens, M.; Pritchard, J.K. Inference of population structure using multilocus genotype data: Dominant markers and null alleles. Mol. Ecol. Notes 2007, 7, 574-578. [CrossRef] [PubMed]

46. Roldàn-Ruiz, I.; Dendauw, J.; Van Bockstaele, E.; Depicker, A.; De Loose, M. AFLP markers reveal high polymorphic rates in ryegrasses (Lolium spp.). Mol. Breed. 2000, 6, 125-134. [CrossRef]

47. De Riek, J.; Calsyn, E.; Everaert, I.; Van Bockstaele, E.; De Loose, M. AFLP based alternatives for the assessment of Distinctness, Uniformity and Stability of sugar beet varieties. Theor. Appl. Genet. 2001, 103, 1254-1265. [CrossRef]

48. Dice, L.R. Measures of the Amount of Ecologic Association between Species. Ecology 1945, 26, 297-302. [CrossRef]

49. Nei, M.; Li, W.-H. Mathematical model for studying genetic variation in terms of restriction endonucleases. Proc. Natl. Acad. Sci. USA 1979, 76, 5269-5273. [CrossRef] [PubMed]

50. XLSTAT Statistical Data and Data Analysis Solution; Addinsoft: New York, NY, USA, 2021.

51. Rohlf, F.J. Exeter Software (Firm) NTSYS-Pc: Numerical Taxonomy and Multivariate Analysis System; Applied Biostatistics, Inc. Exeter Software: Setauket, NY, USA, 2009; ISBN 978-0-925031-31-0.

52. Falush, D.; Stephens, M.; Pritchard, J.K. Inference of Population Structure Using Multilocus Genotype Data: Linked Loci and Correlated Allele Frequencies. Genetics 2003, 164, 1567-1587. [CrossRef]

53. Evanno, G.; Regnaut, S.; Goudet, J. Detecting the number of clusters of individuals using the software structure: A simulation study. Mol. Ecol. 2005, 14, 2611-2620. [CrossRef]

54. Earl, D.A. Structure Harvester: A website and program for visualizing STRUCTURE output and implementing the Evanno method. Conserv. Genet. Resour. 2011, 4, 359-361. [CrossRef]

55. Pritchard, J.K.; Stephens, M.; Donnelly, P. Inference of population structure using multilocus genotype data. Genetics 2000, 155, 945-959. [CrossRef]

56. Bonin, A.; Bellemain, E.; Idesen, P.B.; Pompanon, F.; Brochmann, C.; Taberlet, P. How to track and assess genotyping errors in population genetics studies. Mol. Ecol. 2004, 13, 3261-3273. [CrossRef]

57. Schwarz, G.; Herz, M.; Huang, X.Q.; Michalek, W.; Jahoor, A.; Wenzel, G.; Mohler, V. Application of fluorescence-based semi-automated AFLP analysis in barley and wheat. Theor. Appl. Genet. 2000, 100, 545-551. [CrossRef]

58. Carrasco, B.; Garcés, M.; Rojas, P.; Saud, G.; Herrera, R.; Retamales, J.B.; Caligari, P.D. The Chilean Strawberry [Fragaria chiloensis (L.) Duch.]: Genetic Diversity and Structure. J. Am. Soc. Hortic. Sci. 2007, 132, 501-506. [CrossRef]

59. Meng, F.; Liu, L.; Peng, M.; Wang, Z.; Wang, C.; Zhao, Y. Genetic diversity and population structure analysis in wild strawberry (Fragaria nubicola L.) from Motuo in Tibet Plateau based on simple sequence repeats (SSRs). Biochem. Syst. Ecol. 2015, 63, 113-118. [CrossRef]

60. Lu, J.; Zhang, Y.; Diao, X.; Yu, K.; Dai, X.; Qu, P.; Crabbe, M.J.C.; Zhang, T.; Qiao, Q. Evaluation of Genetic Diversity and Population Structure of Fragaria nilgerrensis using EST-SSR Markers. Gene 2021, 796-797, 145791. [CrossRef] [PubMed] 